\title{
DIFFERENT VOLUMES OF TUBES FOR CLONAL PROPAGATION OF Coffea canephora FROM SEEDLINGS
}

\author{
Marcelo Curitiba Espindula ${ }^{1}$, Tony José Balbino ${ }^{2}$, Rutinéia Jaraceski ${ }^{3}$, Alexsandro Lara Teixeira ${ }^{4}$, \\ Jairo Rafael Machado Dias ${ }^{5}$, Richelly Gisela Pasqualotto Teixeira ${ }^{6}$
}

(Received: November 9, 2016; accepted: Monday, April 3, 2017)

\begin{abstract}
The aim in the present study was to evaluate the growth of Coffea canephora cv. 'Conilon BRS Ouro Preto' seedlings in different tube volumes. The experiment was performed at Embrapa Rondônia plant nursery in Ouro Preto do Oeste, Rondônia, Brazil, from July to November 2013. The treatments consisted of five tube volumes $\left(50,100,170,280\right.$ and $\left.400 \mathrm{~cm}^{3}\right)$ plus one control composed by polyethylene bags $\left(11 \mathrm{~cm}\right.$ width x $20 \mathrm{~cm}$ height) with capacity of $770 \mathrm{~cm}^{3}$. The experimental design was a randomized complete block design with 15 replicates, formed by 15 clones that compose the Conilon 'BRS Ouro Preto' cultivar. The tube volume of $280 \mathrm{~cm}^{3}$ provide the best vegetative performance of seedlings, similarly to volume of 400 $\mathrm{cm}^{3}$, thus, the use of larger tubes would not justify. Tubes of 50,100 and $170 \mathrm{~cm}^{3}$ produce seedlings with physiological quality similar to the control until 130 days after staking, but may limit the development of seedlings in a longer period.
\end{abstract}

Index terms: Vegetative propagation, cuttings, Conilon, BRS Ouro Preto.

\section{DIFERENTES VOLUMES DE TUBETES PARA PRODUÇÃO DE MUDAS CLONAIS DE Coffea canephora}

\begin{abstract}
RESUMO: O objetivo neste estudo foi avaliar o crescimento de mudas de cafeeiros C. canephora 'Conilon - BRS Ouro Preto' em diferentes volumes de tubetes. O experimento foi conduzido no viveiro de produção de mudas da Embrapa Rondônia em Ouro Preto do Oeste, Rondônia, de julho a novembro de 2013. Os tratamentos foram cinco volumes de tubete $(50,100,170$, 280 e $400 \mathrm{~cm}^{3}$ ) mais uma testemunha constituída por um sacolinhas de polietileno com $11 \mathrm{~cm}$ de largura x $20 \mathrm{~cm}$ de altura com capacidade para $770 \mathrm{~cm}^{3}$. O delineamento experimental foi em blocos casualizados com quinze repetições, formadas pelos 15 clones que compõe a variedade 'Conilon - BRS Ouro Preto'. O volume de $280 \mathrm{~cm}^{3}$ e $400 \mathrm{~cm}^{3}$ promove o melhor desempenho vegetativo das mudas, semelhantemente ao volume de $400 \mathrm{~cm}^{3}$, por isso, o uso de tubetes de maiores volumes não se justifica. Tubetes de 50,100 , e $170 \mathrm{~cm}^{3}$ produzem mudas com qualidade fisiológica semelhante ao controle, até 130 dias após o estaqueamento, mas pode limitar o crescimento das mudas em períodos mais extensos.
\end{abstract}

Termos de indexação: Propagação vegetativa, estaquia, Conilon, BRS Ouro Preto.

\section{INTRODUCTION}

The vegetative propagation of Coffea canephora Pierre ex A. Froehner is one of the technologies that favored the increasing crop productivity in the recent decades. Based on this propagation method, it is possible to maintain the genetic characteristics of the matrix plant, guaranteeing crop homogeneity in terms of productivity, yield precocity and grains quality, and obtaining larger grains and maturation uniformity, besides allowing the harvesting scheduling using clones with differentiated maturation cycle (AMARAL et al., 2007; CONTARATO et al., 2010; PARTELLI et al., 2006b). Clonal crops also facilitate the realization of cultural practices, especially when planted in the 'in line clone' system (ESPINDULA et al., 2015).

The vegetative propagation by cuttings is a simple technique with high setting rates of seedlings (ANDRADE JÚNIOR et al., 2013), being consolidated as the most used propagation method in the commercial production of $C$. canephora seedlings (ALMEIDA et al., 2011; PARTELLI et al., 2006b). However, there is little progress in relation to the used containers and substrates.

For commercial production of seedlings, polyethylene bags and a mixture of soil and cow dung supplemented with chemical fertilizers (DIAS; MELO, 2009) are usually used. Such way of propagation has high costs with transport and cultural practices, provides propagation of soil pathogens, especially nematodes, and degrades the environment due to large soil movement (VILLAIN et al., 2010).

In contrast, the use of tubes allows forming seedlings in organic substrates, with greater control of nutrition, easiness of management in the nursery, transport and rapid planting (BRAUN et al., 2007; LISBOA et al., 2012). Furthermore,

\footnotetext{
${ }^{1,4}$ Embrapa Rondônia - BR 364, Km 5,5 - Zona Rural - 76.815-800 - Porto Velho - RO - marcelo.espindula@embrapa.br, alexsandro.teixeira@embrapa.br

2,5,6Federal University of Rondônia/UNIR - Department of Agronomy - Avenida Norte Sul, no 7.300, Nova Morada - 76.940-000 Rolim de Moura - RO - tony-balbino@hotmail.com, jairorafaelmdias@hotmail.com, rishelly.gisela@hotmail.com

${ }^{3}$ State Secretariat for Agriculture of Rondônia/SEAGRI - Avenida Farquar, 2986, Bairro Pedrinhas - 76.801-470 - Porto Velho-RO ruti.jaraceski@gmail.com
}

Coffee Science, Lavras, v. 13, n. 1, p. 33 - 40, jan./mar. 2018 
the twisting of main roots does not occur in these containers, since they are carried vertically through striations present on the inner walls of the container until the hole in the lower base where the pruning of roots occurs in contact with light and oxygen (AMARAL et al., 2007).

Currently, there are several studies related to the development of coffee seedlings by seed in tubes using commercial substrates (DARDENGO et al., 2013; HENRIQUE et al., 2011; MARANA; MIGLIORANZA; FONSECA, 2008; SILVA et al., 2010; VALLONE et al., 2010). However, for clonal seedlings, few scientific articles descript this method.

Several seedling characteristics are influenced by the container size, such as root and shoot growth, and may affect the percentage of survival in the field and crop productivity (LIMA et al., 2006; VALLONE et al., 2009, 2010). Thus, to optimize the volume of containers in the seedling propagation is essential because larger containers can result in unnecessary labor costs, excessive demand for substrates and transportation, besides occupying a larger area in the nursery, raising production costs (AMARAL et al., 2007; CORREIA et al., 2013; DIAS; MELO, 2009).

In this context, the aim in the present study was to evaluate the growth of Coffea canephora cv. 'Conilon BRS Ouro Preto' seedlings in different tube volumes.

\section{MATERIAL AND METHODS}

The experiment was installed in the experimental field of Embrapa Rondônia, in the municipality of Ouro Preto do Oeste, RO, Brazil $\left(10^{\circ} 45^{\prime} \mathrm{S}, 62^{\circ} 15^{\prime} \mathrm{W}\right.$ and $245 \mathrm{~m}$ altitude). The climate of the region is Aw according to the Köppen classification (tropical rainforest climate) with rainy summer (October to May) and dry winter (June to September). The annual average rainfall was $2,000 \mathrm{~mm}$ and annual average temperature of $25{ }^{\circ} \mathrm{C}$.

The cuttings were planted in July 2013 and remained to the nursery until October 2013. The experiment was performed with five treatments consisting of five tube volumes $(50,100,170,280$ and $400 \mathrm{~cm}^{3}$ ) and a control, using polyethylene bags $(11 \mathrm{~cm}$ width x $20 \mathrm{~cm}$ height) with capacity $770 \mathrm{~cm}^{3}$.

The experimental design was the randomized complete block design with 15 replicates. Each replicate was composed by one of the 15 clones from the C. canephora cv. 'Conilon
- BRS Ouro Preto'. The cultivar stands out in the yield per area (average of 70 bags per hectare of processed coffee), as well as in the characteristics of its plants, tolerance to the main diseases and to the abiotic stresses of the coffee tree occurring in the state of Rondônia, Brazil (ROCHA et al., 2015). The experimental plot consisted of six plants.

The tubes were filled with a mixture of commercial substrates, while the polyethylene bags used fertilizer-enriched soil. The materials used in the filling of containers had their chemical properties determined prior to the addition of fertilizers (Table 1). The analyses were performed by the chemical analysis laboratory of the Embrapa in the municipality of Porto Velho, RO, Brazil.

The mixture used in the study consisted of the commercial substrates Bioplant ${ }^{\circledR}$ and Vivatto Plus $^{\circledR}$ in the 2.5:1 ratio. The Bioplant ${ }^{\circledR}$ substrate shows in its formulation pine bark, coconut fiber, vermiculite, rice husk and nutrients. In contrast, the Vivatto Plus ${ }^{\circledR}$ consists of ground charcoal, pine bark and peat. The Basacote Plus ${ }^{\circledR}$ controlled release fertilizer was added to the substrate mixture in the proportion of $6 \mathrm{~kg} \mathrm{~m}^{-3}$. This fertilizer is composed of $16 \% \mathrm{~N}, 8 \% \mathrm{P}_{2} \mathrm{O}_{5}, 12 \% \mathrm{~K}_{2} \mathrm{O}, 2 \% \mathrm{Mg}$ and $5 \% \mathrm{~S}$.

The mixture of $210 \mathrm{~kg}$ soil, $35 \mathrm{~kg}$ sand, $1000 \mathrm{~g}$ limestone, $1000 \mathrm{~g}$ single superphosphate, $200 \mathrm{~g}$ potassium chloride and $80 \mathrm{~g}$ FTE-BR12 was used to fill the polyethylene bags (control).

The containers were filled with substrate 20 days prior to planting of cuttings and packed in the nursery, irrigated by micro sprinkler systems, combined with an automated timer programmed to maintain humidity at approximately $90 \%$ in the first 30 days after planting of cuttings.

In each container, was inserted a vegetative propagule, formed by orthotropic branch segment (cutting) with $4 \mathrm{~cm}$ length according to the recommendations proposed by Ferrão et al. (2007). For standardization of the propagule maturity, only the third node, from the apex to the base, of each orthotropic stem was used.

Fertilization and cultural practices were performed according to the crop needs. From the complete emission of the second pair of definitive leaves, $5 \mathrm{~g}$ urea dissolved in $10 \mathrm{dm}^{3}$ water were applied every 15 days.

The phytosanitary control also occurred every 15 days, alternating the application of systemic fungicide based on tebuconazole prepared at the concentration from $50 \mathrm{~cm}^{3}$ to 20 $\mathrm{L}$ water and a protector based on copper sulphate prepared in the ratio from $100 \mathrm{~g}$ to $20 \mathrm{dm}^{3}$ water. 
TABLE 1 - Chemical properties of substrates formed by the mixture of commercial substrate and soil used in the experiment.

\begin{tabular}{|c|c|c|c|c|c|c|c|c|c|}
\hline & $\mathrm{pH}$ in water & 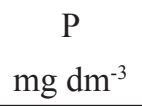 & K & $\mathrm{Ca}$ & $\begin{array}{c}\mathrm{Mg} \\
\mathrm{cmol}_{\mathrm{c}} \mathrm{dm}^{-3}\end{array}$ & $\mathrm{Al}+\mathrm{H}$ & $\mathrm{Al}$ & $\begin{array}{c}\mathrm{OM} \\
\mathrm{g} \mathrm{kg}^{-1}\end{array}$ & $\begin{array}{l}\mathrm{V} \\
\%\end{array}$ \\
\hline Substrates & 5.6 & 890 & 0.31 & 1.54 & 0.74 & 1.15 & 0 & 99.7 & 69 \\
\hline Soil & 6.2 & 4 & 0.37 & 3.72 & 1.01 & 2.97 & 0 & 16.5 & 63 \\
\hline
\end{tabular}

After 98 days of the planting of cuttings, the deltamethrin insecticide was applied to control insects at the concentration from $20 \mathrm{~cm}^{3}$ to 220 $\mathrm{dm}^{3}$ water.

The seedlings remained growing for 130 days, showing four pairs of fully expanded leaves. Afterwards, the seedling were removed from the tube, washed to remove the substrate and taken to the laboratory to determine the vegetative characteristics.

The evaluated properties were root volume (RV) in $\mathrm{cm}^{3}$, determined in graduated beaker by displaced volume difference; number of leaves (NL) and number of nodes (NN), determined by direct counting; stem length (SL) in cm, determined by measuring directly the insertion point of the shoot at the stake to the apical meristem; stem diameter (SD) in $\mathrm{mm}$, determined using a caliper at the base of the orthotropic branch, $3 \mathrm{~cm}$ above the insertion point of the shoot at the stake.

The materials were taken to the convection oven at $65{ }^{\circ} \mathrm{C}$ until reaching a constant mass in order to obtain the root (RDM), stem (SDM) and leaf (LDM) dry mass in g, determined using an analytical balance with a precision of $0.01 \mathrm{~g}$.

It was also determined the shoot dry mass (SHDM), resulting from the sum of the LDM and SDM; total dry mass (TDM), resulting from the sum of the SHDM and RDM; total leaf area (LA) in $\mathrm{cm}^{2}$, determined through the DDA (Digital Area Determiner) free software (FERREIRA; ROSSI; ANDRIGHETTO, 2008) from digital images and Dickson quality index (DQI), obtained by the formula $\mathrm{DQI}=[\mathrm{TDM} /[(\mathrm{SL} / \mathrm{SD})+(\mathrm{SHDM} /$ RDM)] (DICKSON; LEAF; HOSNER, 1960). All characteristics were express by one seedling.

Data were subjected to analysis of variance and, when significant effects were detected, regression analyses were performed $(\mathrm{p} \leq 0.05)$. Data were also subjected to the Dunnett's test $(p \leq 0.05)$ for comparison of treatments with the control.

\section{RESULTS AND DISCUSSION}

All vegetative characteristics were influenced by the studied tube volumes, with exponential trendlines increasing to the maximum point (Figure 1).

There was increase in the vegetative performance of seedlings with the increased tube volume. The growth of plant, shoot and root system as a function of the container volume corroborate with the results reported for Toona ciliata M. Roem. (LISBOA et al., 2012), Cordia trichotoma (Vell.) Arráb. ex Steud. and Jacaranda micranta Cham.(MALAVASI; MALAVASI, 2006), C. arabica (VALLONE et al., 2009), Hymenaea courbaril L., Tabebuia chrysotricha (Mart. ex DC.) Standl.and Parapiptadenia rigida Benth. (FERRAZ; ENGEL, 2011), Ricinus communis L. (LIMA et al., 2006) and Pinus taeda L.(DOBNER JÚNIOR et al., 2013).

Such increase is resulting of a greater area available for root exploration inside the containers, providing a greater development of the root system, greater availability of water and nutrients and better seedling formation, minimizing stress due to lack of water, which can limit the metabolism, influencing the shoot development of the plant (DOBNER JÚNIOR et al., 2013; FERRAZ; ENGEL,2001; MALAVASI; MALAVASI, 2006; STAPE et al., 2010).

The volumes of 50 and $100 \mathrm{~cm}^{3}$ showed values of stem length (SL), stem diameter (SD), leaf area (LA), leaf dry mass (LDM), stem dry mass (SDM), root dry mass (RDM), shoot dry mass (SHDM), total dry mass (TDM) and Dickson quality index (DQI) similar to the control, while the 170,280 and $400 \mathrm{~cm}^{3}$ volumes showed values higher than control. For the root volume (RV), only the volumes of 280 and $400 \mathrm{~cm}^{3}$ presented results significantly higher than the control (Table 2). 
(A)

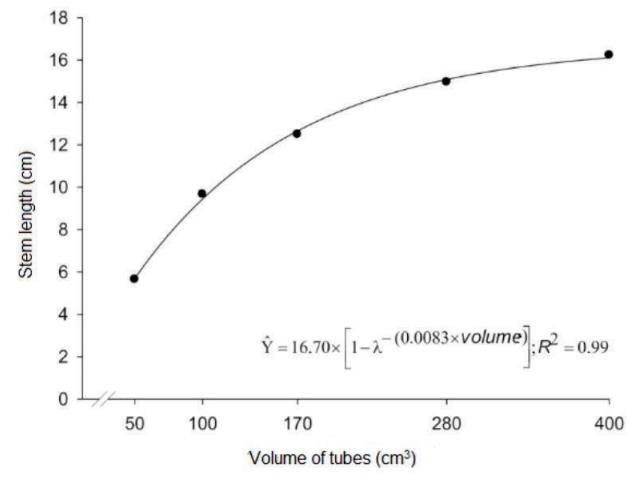

(C)

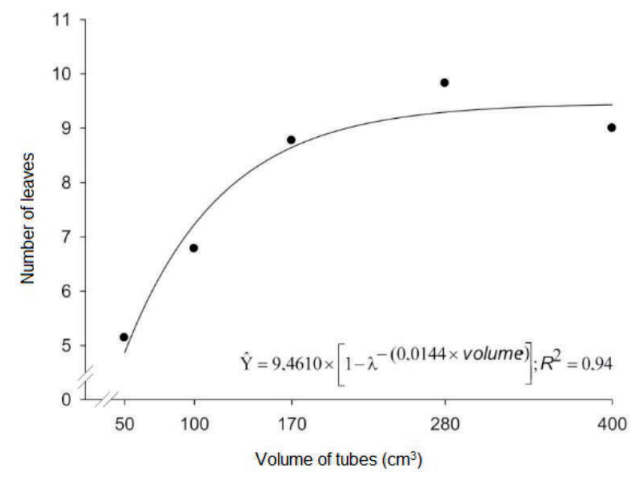

(E)

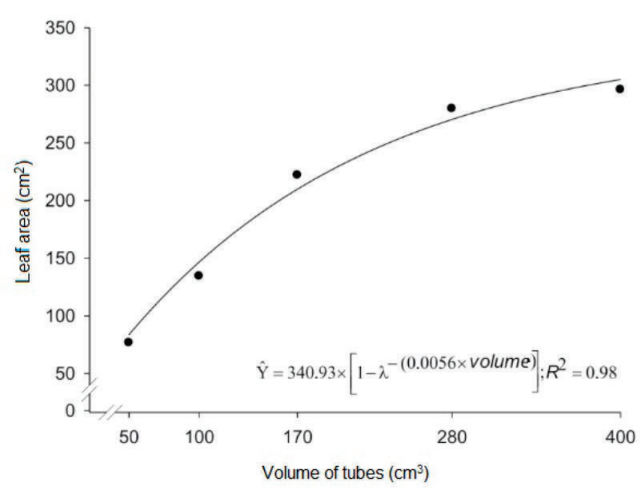

(G)

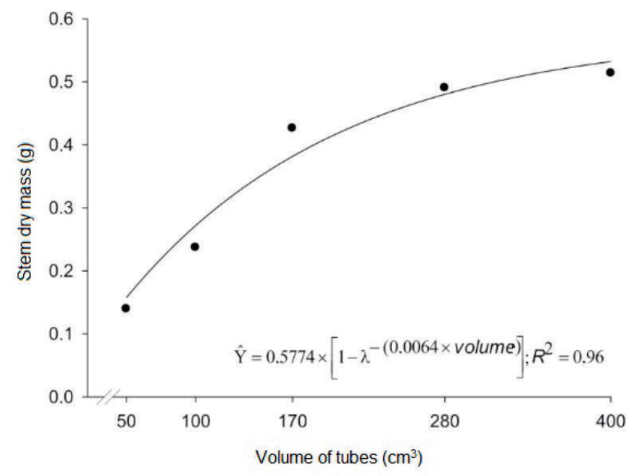

(B)

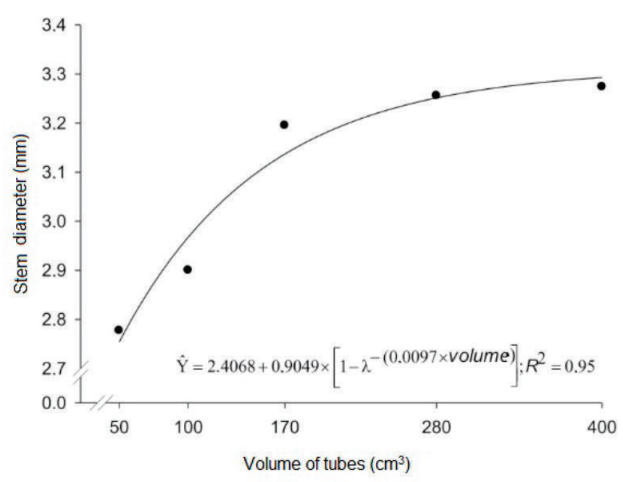

(D)

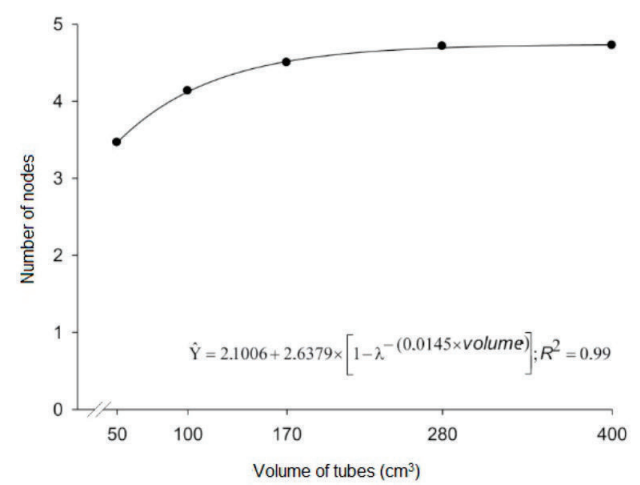

(F)

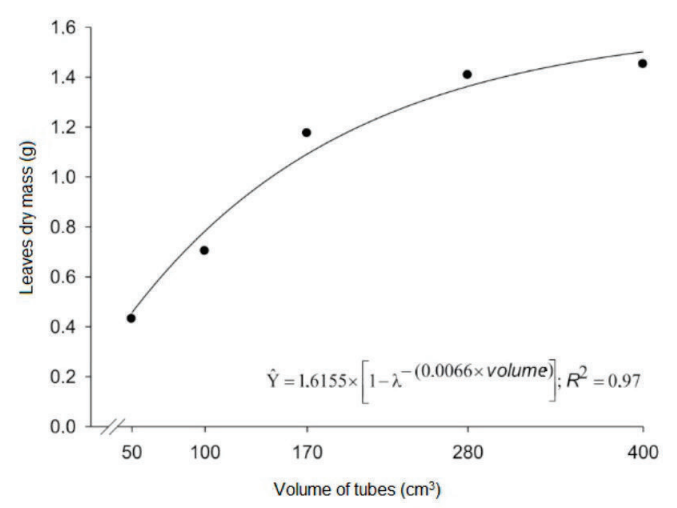

(H)

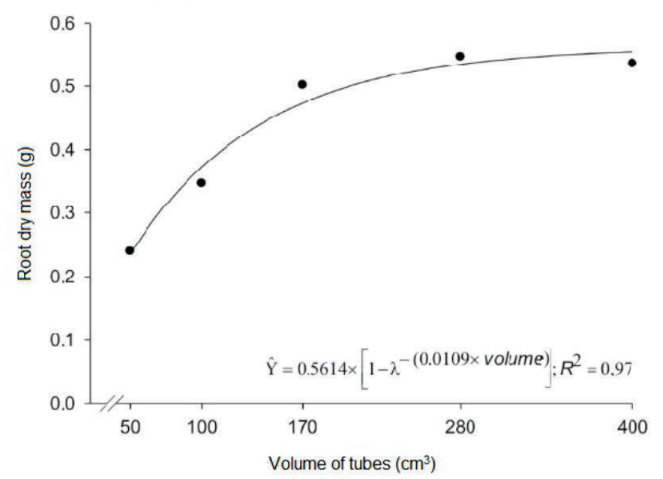

Coffee Science, Lavras, v. 13, n. 1, p. 33 - 40 jan./mar. 2018 
(I)

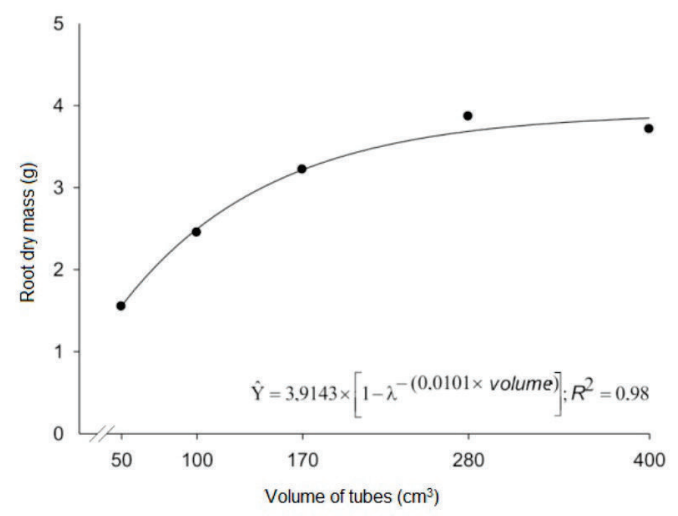

(K)

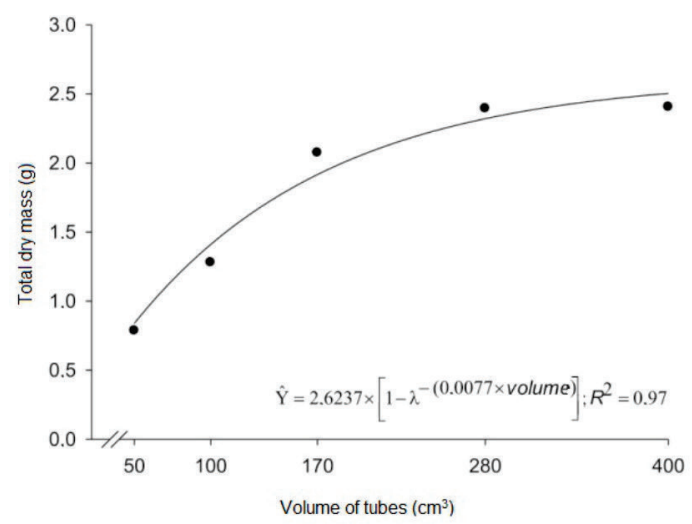

(J)

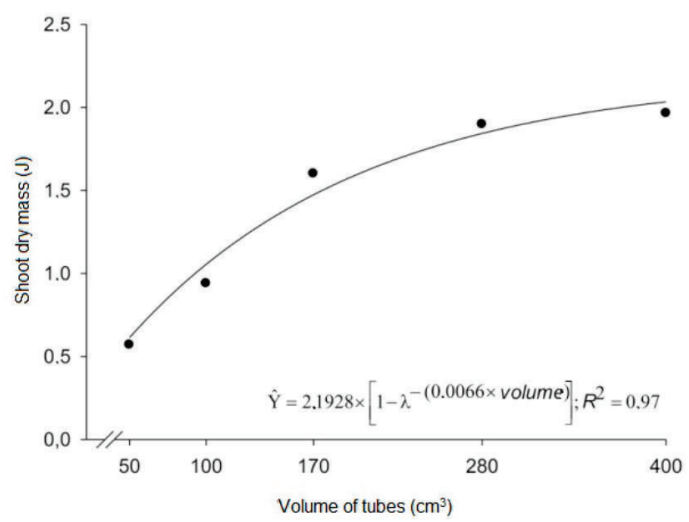

(L)

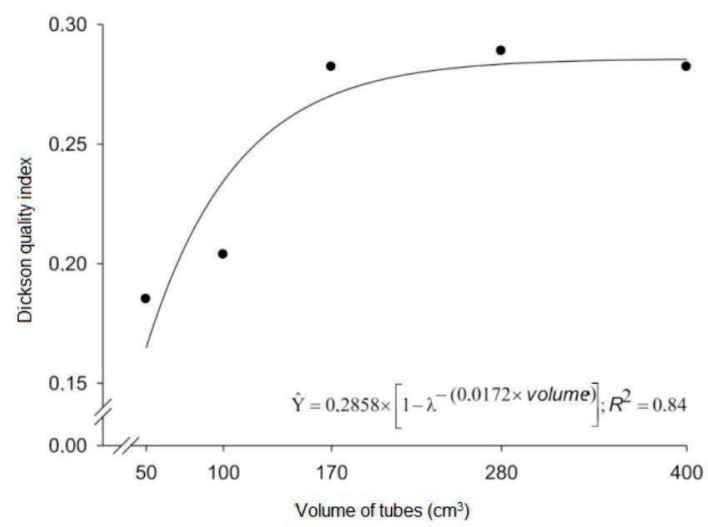

FIGURE 1 - Stem length (cm) (A), stem diameter (mm) (B), number of leaves (C), number of nodes (D), leaf area $\left(\mathrm{cm}^{2}\right)(\mathrm{g})$, leaves dry mass $(\mathrm{F})$, stem dry mass $(\mathrm{g})$, root dry mass $(\mathrm{g})(\mathrm{H})$, root volume $\left(\mathrm{cm}^{3}\right)(\mathrm{I})$, shoot dry mass $(\mathrm{J})$, total dry mass $(\mathrm{g})(\mathrm{K})$, Dickson quality index $(\mathrm{L})$ of Coffea canephora seedlings propagated in different tube volumes. All characteristics are express by one seedling.

The values obtained for stem length (SL) and stem diameter (SD) were higher than the presented by Braun et al. (2007) in C. canephora seedlings with 140 days of nursery, and by Dardengo et al. (2013), working with different containers and levels of shading in C. canephora seedlings with 160 days, 30 days longer than the seedlings propagated in the present experiment.

The SL and SD are important characteristics to evaluate the quality of seedlings. Seedlings of higher stem diameter show greater capacity for emission of new roots (NOVAES et al., 2002), providing resistance to environmental stress conditions, ensuring higher survival rates and initial development after planting in the field (FREITAS et al., 2005).

The treatments with 170,280 and $400 \mathrm{~cm}^{3}$ showed values of RDM, SHDM and TDM higher than the reported by Berilli et al. (2014), working with different substrates in polyethylene bags. The averages obtained for the DQI were between 0.18 and 0.28 . The values are close to the cited by Hount (1990) and Marana, Miglioranza and Fonseca (2008), which recommend DQI values above 0.20 as ideal for seedlings. Gomes et al. (2013) stated that this index is efficient to evaluate the quality and robustness of seedlings, incorporating in the calculation values related to the growth and accumulation of dry matter.

The volume vs. control interaction did not influence the NL and NN, but was significant for LA, in which the tubes 170,280 and $400 \mathrm{~cm}^{3}$ were superior to the control. It was also possible to observe that this increased LA of seedlings was proportional to the increase in the tube volume (FIGURE 1). 


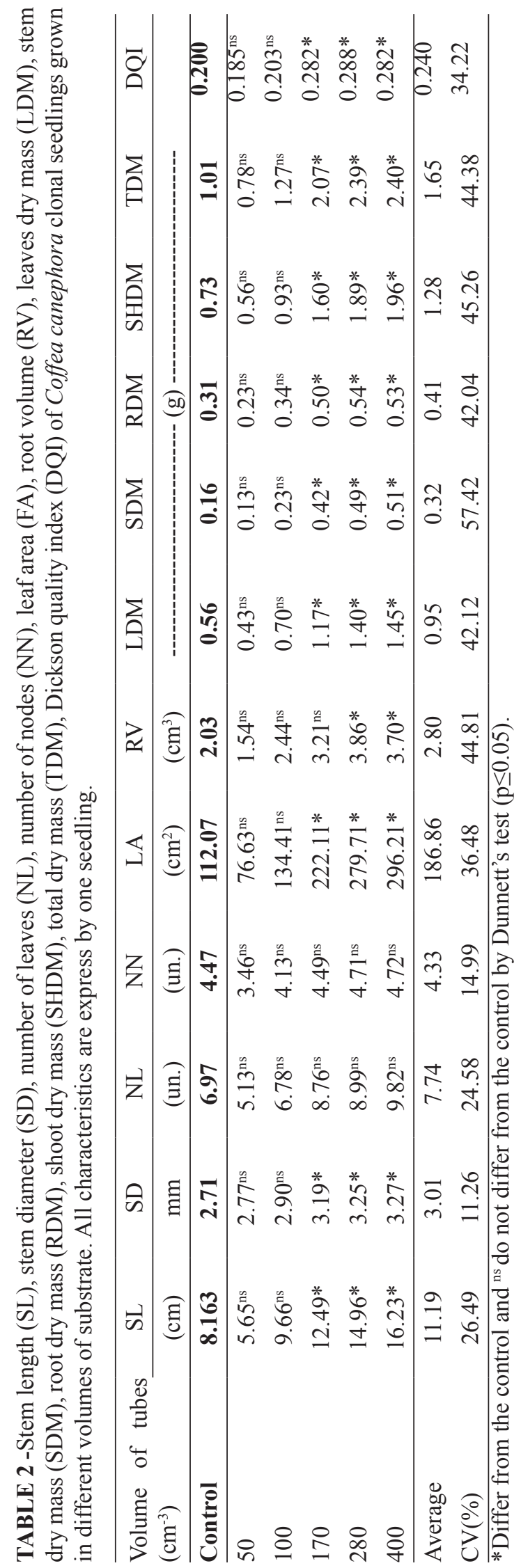

The increase in LA provides a greater ability to intercept light, thus promoting plant development (PARTELLI et al., 2006a).

The LA values were also higher than the best values obtained by Dardengo et al. (2013). For the tubes 170, 280 and $400 \mathrm{~cm}^{3}$, the LA values were higher than obtained by Lemos et al. (2015) in coffee plants subjected to the application of different concentrations of citric acid and phosphorus in the substrate, demonstrating satisfactory seedling growth in the present experiment.

In short, the study results indicate that higher tube volumes can promote a vigorous and balanced development between shoot and root system. On the other hand, Lemos et al. (2015) emphasized that the substrate represents a high value in the production cost. Thus, how the tube of $280 \mathrm{~cm}^{3}$ showed enough vegetative development of seedlings, the use of larger tubes would not justify.

The container size must be considered too in relation to the time that seedlings will remain in the nursery before the final planting in the field. This is because, even considering that the volumes of 50 and $100 \mathrm{~cm}^{3}$ did not differ from the control, the permanence of seedlings in these containers for a period superior to the studied could promote delayed growth and development of seedlings in the field.

\section{CONCLUSIONS}

The tube volume of $280 \mathrm{~cm}^{3}$ provide the best vegetative performance of seedlings, similarly to volume of $400 \mathrm{~cm}^{3}$, thus, the use of larger tubes would not justify.

Tubes of 50, 100 and $170 \mathrm{~cm}^{3}$ produce seedlings with physiological quality similar to the control until 130 days after staking, but may limit the development of seedlings in a longer period.

\section{REFERENCES}

ALMEIDA, G. R. R. et al. Comportamento de cafeeiros propagados por embriogênese somática e por sementes em diferentes níveis de água no solo. Coffee Science, Lavras, v. 6, n. 2, p. 114-119, maio/ago. 2011.

AMARAL, J. A. T. et al. Crescimento vegetativo e produtividade de cafeeiros Conilon propagados por estacas em tubetes. Ciência e Agrotecnologia, Lavras, v. 31, n. 6, p. 1624-1629, nov./dez. 2007.

Coffee Science, Lavras, v. 13, n. 1, p. 33 - 40 jan./mar. 2018 
ANDRADE JÚNIOR, S. et al. Comparison between grafting and cutting as vegetative propagation methods for conilon coffee plants. Acta Scientiarum Agronomy, Maringá, v. 35, n. 4, p. 461-469, out. 2013.

BERILLI, S. S. et al. Utilização de lodo de curtume como substrato para produção de mudas de café Conilon. Coffee Science, Lavras, v. 9, n. 4, p. 472-479, out./dez. 2014.

BRAUN, H. et al. Produção de mudas de café 'conilon' propagadas vegetativamente em diferentes níveis de sombreamento. Idesia, Arica, v. 25, p. 85-91, dic. 2007.

CONTARATO, C. C. et al. Evaluation of the initial development of conilon coffee clones (Coffea canephora). Scientia Agraria, Curitiba, v. 11, n. 1, p. 65-71, jan./fev. 2010.

CORREIA, A. C. G. et al. Volume de substratos e idade: Influência no desempenho de mudas clonais de eucalipto após o replantio. Cerne, Lavras, v. 19, n. 2, p. 185-191, jun. 2013.

DARDENGO, M. C. J. D. et al. Crescimento e qualidade de mudas de café Conilon produzidas em diferentes recipientes e níveis de sombreamento. Coffee Science, Lavras, v. 8, n. 4, p. 500-509 out./dez. 2013.

DIAS, R.; MELO, B. Proporção de material orgânico no substrato artificial para a produção de mudas de cafeeiro em tubetes. Ciência e Agrotecnologia, Lavras, v. 33, n. 1, p. 144-152, jan./fev. 2009.

DICKSON, A.; LEAF, A. L.; HOSNER, J. F. Quality appraisal of white spruce and white pine seedling stock in nurseries. Forestry Chronicle, Ottawa, v. 36, n. 1, p. 10-13, 1960.

DOBNER JÚNIOR, M. et al. Influência do volume do tubete e do método de plantio no crescimento de um povoamento de Pinus taeda aos nove anos de idade. Scientia Forestalis, Piracicaba, v. 41, n. 97, p. 7-14, mar. 2013.

ESPINDULA, M. C. Condução de cafeeiros Coffea Canephora. In: In: MARCOLAN, A.; ESPINDULA, M. C. (Ed.). Café na Amazônia. Brasília, DF: EMBRAPA, 2015. p. 217-236.

FERRÃO, R. G. et al. Café Conilon. Vitória: Incaper, 2007. 702 p.
FERRAZ, A. V.; ENGEL, V. L. Efeito do tamanho de tubetes na qualidade de mudas de jatobá (Hymenaea courbaril L. var. stilbocarpa (Hayne) Lee et Lang.), ipê-amarelo (Tabebuia chrysotricha (Mart. ex Dc.) Sandl.) e guarucaia (Parapiptadenia rigida (Benth.) Brenan). Revista Árvore, Viçosa, v. 35, n. 3, p. 413423, abr. 2011.

FERREIRA, O. G. L.; ROSSI, F. D.; ANDRIGHETTO, C. DDA - Determinador Digital de Áreas: software para determinação de área foliar, índice de área foliar e área de olho de lombo. Versão 1.2. Santo Augusto: IF Farroupilha, 2008.

FREITAS, T. A. S. et al. Desempenho radicular de mudas de eucalipto produzidas em diferentes recipientes e substratos. Revista Árvore, Viçosa, v. 29, n. 6, p. $853-861,2005$.

GOMES, D. R. et al. Lodo de esgoto como substrato para a produção de mudas de Tectona grandis L. Cerne, Lavras, v. 19, n. 1, p. 123-131, jan./mar. 2013.

HENRIQUE, P. C. et al. Aspectos fisiológicos do desenvolvimento de mudas de café cultivadas sob telas de diferentes colorações. Pesquisa Agropecuária Brasileira, Brasília, DF, v. 46, n. 5, p. 458-465, maio 2011.

HUNT, G. A. Effect of styroblock design and cooper treatment on morphology of conifer seedlings. In: TARGET SEEDLING SYMPOSIUM, MEETING OF THE WESTERN FOREST NURSERY ASSOCIATIONS, GENERAL TECHNICAL REPORT RM-200, 1990, Roseburg. Proceedings... Fort Collins: USDA, Forest Service, 1990. p. 218-222.

LEMOS, V. T. et al. Ácido cítrico e fósforo no desenvolvimento e estado nutricional de mudas de café. Coffee Science, Lavras, v. 10, n. 3, p. 298-308, jul./set. 2015.

LIMA, R. L. S. et al. Volume de recipientes e composição de substratos para produção de mudas de mamoneira. Ciência e Agrotecnologia, Lavras, v. 30, n. 3, p. 480-486, maio/jun. 2006.

LISBOA, A. C. et al. Efeito do volume de tubetes na produção de mudas de Calophyllum brasiliense e Toona ciliata. Revista Árvore, Viçosa, v. 36, n. 4, p. 603-609, jul./ago. 2012.

MALAVASI, U. C.; MALAVASI, M. M. Efeito do volume de tubete no crescimento inicial de plântulas de Cordia trichotoma (Vell.) Arrab. ex Steud e Jacaranda micranta Cham. Ciência Florestal, Santa Maria, v. 16, n. 1, p. 11-16, 2006. 
MARANA, J. P.; MIGLIORANZA, E.; FONSECA, E. P. Índices de qualidade e crescimento de mudas de café produzidas em tubetes. Ciência Rural, Santa Maria, v. 38, p. 39-45, jan./fev. 2008.

NOVAES, A. B. et al. Avaliação do potencial de regeneração de raízes de mudas de Pinus taeda L. produzidas em diferentes tipos de recipientes e o seu desempenho no campo. Revista Árvore, Viçosa, v. 26, n. 6, p. $675-681,2002$.

PARTELLI, F. L. et al. Estimativa da área foliar do cafeeiro conilon a partir do comprimento da folha. Revista Ceres, Viçosa, v. 53, n. 306, p. 204-210, mar./ abr. 2006a.

Produção e desenvolvimento radicular de plantas de café 'Conilon' propagadas por sementes e por estacas. Pesquisa Agropecuária Brasileira, Brasília, DF, v. 41, n. 6, p. 949-954, jun. 2006b.

ROCHA, R. B. et al. Melhoramento genético de Coffea canephora: considerações e metodologias. In: MARCOLAN, A.; ESPINDULA, M. C. (Ed.). Café na Amazônia. Brasília, DF: EMBRAPA, 2015. p. 101-122.
SILVA, J. I. et al. Desenvolvimento de mudas de Coffea canephora pierre ex a. Froehner em diferentes combinações de substrato e recipiente. Coffee Science, Lavras, v. 5, n. 1, p. 38-48, jan./abr. 2010.

STAPE, J. L. et al. The Brazil Eucalyptus potential productivity project: influence of water, nutrients and stand uniformity on wood production. Forest Ecology and Management, Amsterdam, v. 259, p. 1684-1694, 2010.

VALLONE, H. S. et al. Diferentes recipientes e substratos na produção de mudas de cafeeiros. Ciência e Agrotecnologia, Lavras, v. 34, n. 1, p. 55-60, jan./ fev. 2010.

- Recipientes e substratos na produção de mudas e no desenvolvimento inicial de cafeeiros após o plantio. Ciência e Agrotecnologia, Lavras, v. 33, n. 5, p. 1327-1335, set./out. 2009.

VILLAIN, L. et al. A high-throughput method for early screening of coffee (Coffea spp.) genotypes for resistance to root-knot nematodes (Meloidogyne spp.). European Journal Plant Pathology, Dordrecht, v. 128, p. 451-458, 2010. 